\title{
ENLARGEMENT PREFERENCES AND POLICY-MAKING IN THE EUROPEAN UNION: IMPACTS ON TURKEY
}

\author{
MELTEM MÜFTÜLER-BAC and LAUREN M. MCLAREN \\ ${ }^{\mathrm{a}}$ Sabanci University, Istanbul; ${ }^{\mathrm{b}}$ University of Oxford
}

(Received 12 September 2002; In final form 28 November 2002)

\begin{abstract}
European Union policy changed considerably towards Turkey between 1997 and 1999. This paper analyses the circumstances surrounding this change, focusing on (a) the modification in the overall enlargement strategy of the EU and (b) the effect of the change in particular member states' preferences with regard to Turkish candidacy. We contend that these two developments converged to produce a rather dramatic alteration in policy towards Turkey from one of exclusion to one of inclusion.
\end{abstract}

Keywords: Turkey; European Union; Enlargement; Principle of Differentiation; Preferences.

\section{INTRODUCTION}

The European Union is faced with the most extensive process of enlargement in its history, with twelve candidates currently negotiating accession deals. Upon the Commission's recommendation in its Agenda 2000, the EU formally opened accession talks with all of the Central and Eastern European applicants and Cyprus at the 1997 Luxembourg European Council Summit. The only still - pending application at that point was that of Turkey, which had applied for full EU membership in 1987. ${ }^{1}$ Turkish leaders were rather surprised (and offended) when Turkey was not included in the list of candidates in Luxembourg, especially considering that other seemingly unqualified applicants, like Romania and Bulgaria, were included. ${ }^{2}$ However, the Luxembourg Summit set off a whirlwind of activity in Turkish-EU relations that eventually culminated in the granting of formal candidacy status to Turkey two years later at the European Council's Helsinki Summit.

Given that domestic circumstances within Turkey had not changed much in those two years, ${ }^{3}$ the puzzle that this article addresses is that of the reasons behind the change in EU policy towards Turkey between 1997 and 1999. In order to answer this question, the paper

The authors would like to thank Pelek Karatekelioglu for assistance with this research and Erik Jones for his very useful comments on an earlier draft of the paper.

* Corresponding author: Meltem Müftüler-Bac, Associate Professor of International Relations, Sabanci University, Istanbul. Email: muftuler@sabanciuniv.edu. 
analyses the preferences of EU member states with regard to enlargement generally and regarding the eventual inclusion of Turkey into the European Union. It also outlines the way in which the granting of candidate status to Turkey fits within the realm of the logic of the EU's principle of differentiation, a principle that made Turkey's candidacy more possible than it had been before the principle was articulated at the Cologne Summit of June 1999.

We contend that an analysis of these recent events in Turkish-EU relations is important because of the rather unusual nature of the Turkish candidacy and the level of importance that this particular candidacy poses for stability in the region. First, unlike all of the other candidate countries, Turkey has been associated with the EU since 1963 with an eye towards possible membership. Second, it has been in the process of democratising for well over fifty years and has been converting to a free-market economy for almost twenty years. ${ }^{4}$ In other words, its preparation for being accepted into the realm of European democratic capitalism has been long, especially in comparison to the other current candidate countries. Third, and perhaps even more troubling is another unusual factor about this particular candidate, which is that it faces (mostly unspoken) questions regarding its European credentials. Specifically, some have doubts about whether the country should be eligible for EU membership at all, either due to its Muslim background or to its continuing difficulty with democratisation. That is to say, it seems to be the only candidate for whom there is considerable doubt regarding whether it will ever be accepted as a full EU member due to these perceived cultural differences. Finally, there are unspoken reservations given the size of its population, which is almost twice the size of the largest of the other candidates, Poland.

At the same time, relations between Turkey and the EU are likely to have a tremendous impact on the functioning of Turkish democracy and in turn, the stability of the region. Turkey is a rather central actor in the European security order because of its NATO membership and its geostrategic position, and for these reasons, most European leaders would rather see Turkey incorporated within the realm of Europe than see it isolated. In addition, it is the only secular democracy among the rest of the Muslim countries in the region and European leaders would like to keep it anchored to the West. As the case of the Greek, Spanish, and Portuguese democratisation processes showed European leaders, the carrot of EU membership might play some role in keeping a country like Turkey on the path to full democratisation. In contrast, none of the other candidate countries appear to face the same sorts of threats to their democratisation process that in turn threaten regional stability. In sum, because Turkish membership of the EU is so important to the internal stability of Turkey itself and thus to regional stability, it is important to investigate the recent change in relations between the two parties.

There are three primary theoretical perspectives that might explain enlargement policy making in the EU - rational institutionalism - intergovernmentalism, sociological institutionalism - constructivism, and historic institutionalists' path dependency. The article briefly discusses these theoretical approaches below and contends that, while the latter two offer useful insights into the enlargement process in general, they cannot explain the pace of the enlargement, the bargains that are struck during negotiations, nor the specific change in policy toward Turkey between 1997 and 1999. Instead, these aspects of enlargement should be evaluated in light of policy preferences of the member states, through intergovernmentalist lenses. Thus, the paper analyses member state preferences in terms of enlargement in general and how these preferences affect the EU's policy toward Turkey. Specifically, the questions posed are: what were the factors, i.e. the states' preferences, which led to the Luxembourg decision not to include Turkey in the list of candidate countries? Why was there a change of heart in the EU two years later? This paper proposes 
that, given the fact that political and economic conditions in Turkey did not change dramatically in that two-year period, the answer to these questions can be found by analysing EU members' preferences. This is a novel approach to Turkish-EU relations because previous work on this problematic focused either on historical processes or the obstacles to Turkey's integration. ${ }^{5}$ This paper, therefore, aims to take the debate on Turkish-European Union relations forward by placing this issue within a theoretical perspective of preferences and policy making in the EU.

We begin this analysis of the Luxembourg-Helsinki shift in EU policy towards Turkey with a brief overview of the history of relations between Turkey and the EU. This is then followed by a discussion of the circumstances surrounding the EU's somewhat dramatic change of heart between the summits, including a discussion of the change in the overall enlargement strategy and the effect of this change on relations with Turkey. The article also analyses key member state preferences regarding Turkey at the two time periods. In the analysis of these preferences, the article relies in part upon interviews conducted with thirteen of the EU member states' ambassadors to Turkey in Ankara from October 2000 to December 2000. ${ }^{6}$ However, the arguments presented are also supported by other sources, as ambassadors are unlikely to be completely forthcoming during formal interviews. Finally, the paper discusses important post-Helsinki developments in the realm of Turkish-EU relations.

\section{THEORETICAL APPROACH}

The European Union operates as a 'multi-level' system of governance. ${ }^{7}$ It is a good example of the tensions between two opposing tendencies: supranationalism on the one hand and intergovernmentalism on the other. EU policy-making has components of each. ${ }^{8}$ At the intergovernmental level, the relative power of member states determines which states' preferences will be reflected in EU policies. ${ }^{9}$ Enlargement issues are decided mostly in intergovernmental bargaining processes where states' preferences and relative power become the determining factors. ${ }^{10}$ This is because enlargement and the EU's external relations are particularly delicate issue areas where the EU members would like to have the final word. Member states are still in control of EU membership, and expansion (as a foreign policy issue) is perceived as one of the last remnants of state sovereignty. "At the most extreme point, EU enlargement internalises political space in the EU ... Whether the EU maintains, blurs or moves its boundaries will therefore in the last resort depend on its ability to strike a balance between the benefits and costs involved for each member state." 11

The intergovernmental method of decision making in the EU allows members to cut deals with one another and bypass the supranational power of the Community institutions for key policies such as enlargement. This is why member states' egoistic interests and cost/benefit calculations determine major EU policies. One alternative to this rational, self-interested approach is historic institutionalism, which emphasises the self-running character of the enlargement process through the conceptual lenses of path dependency: "Path dependent processes continue irrespective of whether the initial decision still makes sense, and explains why actors stick to their guns even though their short term instrumental interests might have changed." 12 This theoretical approach would then explain the EU's policy toward Turkey as part of a linear process that began with (a) a promise of eventual EU membership to Turkey in its original 1963 association agreement and (b) the commitment of the EU to another enlargement. Once these decisions were made, leaving Turkey out of the EU's enlargement 
became impossible. However, it fails to explain why Turkey was excluded from this process in 1997 and brought back in by the end of 1999.

A third approach, the constructivist criticism of rational institutionalism, emphasises that it is the collective identity of EU members that determines preferences and policy outcomes. ${ }^{13}$ For instance, Commission President Romano Prodi states that enlargement is "a political act that calls for a review and the recasting of the political pact on which the Union is based." ${ }^{14}$ Lionel Jospin, French Prime minister, states that "the enlargement of the EU is a historic necessity" 15 and German Chancellor Schroeder claims "enlargement is necessary both politically and morally." 16 The actors' perceptions about their enlargement preferences are thus shaped by their vision of the future of the EU. The constructivist school maintains that it is the expansion of the liberal community that the EU symbolises that triggered the EU's enlargement process and kept it on track despite the diverging preferences of the members. This approach might argue that the EU granted Turkey candidacy to help establish stable liberal democracy. However, sociological institutionalism cannot adequately account for the EU's change of heart towards Turkey either, given the fact that Turkish democracy was no worse in 1997 than in 1999.

In sum, constructivism provides an understanding into the basic ideal behind enlargement as the expansion of a liberal community - and historic institutionalism explains how once an enlargement decision is made, it becomes path dependent. While both of these alternative approaches - historic institutionalism and constructivism - offer insight into the enlargement process in general and into the EU's decision to grant Turkey candidacy, this paper contends that neither of these approaches can fully explain the current deals that are being cut regarding the next enlargement, nor can they explain the timing of the sudden shift in policy toward Turkey. Both of these are fundamentally dependent on the interests of the member states and their power in influencing enlargement policy. It is for this reason that our approach - which focuses on the EU members' preferences - is theoretically important to understand the scope, pace and nature of enlargement. A thorough understanding of Turkey's position in the EU enlargement process depends on the interplay of the propositions from these different theoretical lenses. Thus, in the following sections, we briefly introduce Turkey's relations with the EU and then proceed to an analysis of member state preferences in the realm of enlargement and the effect that these preferences have on the Turkish candidacy.

\section{HISTORY OF TURKISH-EU RELATIONS}

Turkey became an Associate member of the EC/EU when it signed the Ankara Treaty/ Association Agreement on 12 September 1963, and has had the longest association with the European Union among the candidate countries. It signed an Additional Protocol in 1970 and a Customs Union Agreement - as foreseen by the Association Agreement - in 1995. In fact, Turkey is the only country that realised a Customs Union on industrial products with the EU prior to full membership.

The granting of candidate status to Turkey can be traced to some degree to its 1963 Association Agreement - the Ankara Treaty - with the European Economic Community. As with the Greek Association Agreement, which was signed close to the same time, the Ankara Treaty was clear about the fact that full Turkish membership of the EEC might be foreseen at some unstipulated future date if and when both parties could fulfil their obligations of membership. Despite this hopeful beginning, Turkish-EU relations were often rather difficult. The difficulties sometimes stemmed from the perception on the part of Turkish 
leaders that the EU was not fulfilling its side of the association agreement such as its obligations under Financial Protocols and free movement of persons. Other difficulties revolved around domestic problems in Turkey that eventually culminated in a military coup in 1980, after which ties with the EU were temporarily severed, as the EU refuses to have association agreements with non-civilian governments.

When Turkey applied for full membership of the Community in 1987 (after holding democratic elections in 1983), the Commission's response to the Turkish application two years later was that the EU was in the process of trying to integrate its three new member states and was also at the early stages of completing the common market, and that it could not consider new applications from any potential candidates at that time. The Turkish application was not rejected outright, but was clearly not going to be considered in the short term. This was a rather unexpected outcome, and was the first major event that led to serious doubts about whether Turkey would ever be granted EU membership, or whether the prejudice against Turkey from within the EU was simply too strong (for the reasons noted above). ${ }^{17}$

The second such major event came in 1997 with the Luxembourg Summit, where Turkey's application, which had been on the table for ten years, was apparently ignored, despite the hopes raised by the experience of the Customs Union with the EU. This outcome provoked extremely hostile reactions from within Turkey, and led to even further doubt about whether the EU was serious about ever including Turkey. In response to the Luxembourg decision, Turkey froze all political dialogue with the EU and declined to participate in the European Conference convened in March 1998 for candidate countries. At the following summit in Cardiff, the EU issued an encouraging statement to Turkey, but still did not make the country a candidate. Finally, in what is perceived as a major breakthrough, the EU reversed its policy and granted the desired candidacy status in Helsinki in December 1999. We turn now to an analysis of how this unexpected change came about.

\section{FROM LUXEMBOURG TO HELSINKI: THE ENLARGEMENT PROCESS AND TURKEY'S CANDIDACY}

In theory, all EU member states were committed to the enlargement of the EU 'as an irreversible process', as declared at the 2001 Gothenburg European Council summit. However, EU member states, once committed to the general idea of enlargement, had different levels of support for certain candidates' memberships, which were often determined by their self-interest. ${ }^{18}$ This paper contends that these interests are part of the key to explaining the nature of accession negotiations, as well the process of granting candidacy to applicant countries. Thus, for the above-mentioned interviews with EU member state ambassadors to Turkey, one question this article had hoped to investigate was the following: are some member states more enthusiastic about enlargement, specifically towards the accession of some of the candidates and if so why? In order to reveal such preferences, we posed the following questions to our interview respondents: (i) which member states are most in favour of enlargement? (ii) Which member states are least in favour of enlargement? (iii) What factors determine a candidate country's bargaining power with the EU? One of our respondents made the following revealing comment in response to these questions, and it was echoed by several other ambassadors in separate interviews: "member states with clients would like to see these clients come in". ${ }^{19}$ The analysis begins by discussing this notion of clients in the realm of enlargement policy, and then applies this idea to the Turkish case to explain the turn of events from 1997-9. 
First, Germany clearly appears to have taken Poland as its 'client', perhaps partly to pay Poland back for past atrocities committed there, but also for strategic reasons. ${ }^{20}$ This argument was very clear in the interviews with ambassadors, as almost all interviewees stressed the strong German interests regarding the Visegrad Three, especially towards Poland. Of course, the German government has made its approach quite clear in other contexts as well. According to Chancellor Gerhard Schroeder: "Take it as a political commitment on the part of Germany: in view of the German Chancellor, Poland will be among the first of these countries to join the EU . . Polish membership is a requirement of historical justice." 21

Germany also pushed hard for the inclusion of Hungary and the Czech Republic, again for the purpose of increasing Germany's sense of security. According to Joschka Fischer, the German Foreign Minister, if the EU did not enlarge to include the Central Eastern European countries, Europe would "become a continent of uncertainty ... if that happened Germany in particular would be the big loser." 22 Another possible explanation for this strong support for the Visegrad Three is what Sjursen refers to as "a sense of kinship-based duty" (which she argues is lacking in the Turkish case). ${ }^{23}$

For similar reasons of kinship and strategy, the Nordic countries were the first to press for the inclusion of the Baltic States as EU candidates. Denmark was, in fact, the only Nordic state that was an EU member when the Baltic countries applied for membership and Denmark alone began convincing the other EU members that the Baltic States should indeed be included in the candidate list. When Sweden and Finland joined the EU, they strongly supported Denmark's position, and it is primarily because the Baltic States had so many advocates from within the EU that they were given candidacy status. ${ }^{24}$ Sweden in particular is known to have pressed the EU to broaden the Luxembourg list to include Lithuania and Latvia. ${ }^{25}$ Furthermore, it is likely that it is because of this client relationship that Estonia was included in the original list of frontrunners for full EU membership. As one of the Nordic ambassadors bluntly stated regarding his own country, "[we] favour the Baltic States and that is why [we are] for enlargement in the first place." 26

In addition, the patron-client relationship between France and Romania was strongly emphasised by four of the thirteen ambassadors who were interviewed. One motive for the French leaders to support Romanian membership is that they need a relatively large ally to counter the growing weight of the central European contingent within the European Union and maintain control over Germany's ever-increasing political power. According to a senior French official, "Preventing the rise of German power has been a French national goal almost since Richelieu." 27 Thus, France became Romania's advocate during discussions of NATO expansion, and continued in this role during the Luxembourg Summit, during which Romania - despite extreme political and economic underdevelopment (see endnote 2) - was included in the candidate list. President Chirac's statement that "We will indeed support the candidacy of Romania despite the reticence expressed by the American government" 28 is a testimony in that regard.

In the case of Turkey, one aspect of its problem in gaining formal candidacy is that it did not have a patron-client relationship with any member state. In other words, it is unlikely that it had a patron pushing for its candidacy in Luxembourg, and like Romania, which is also very large and poor, Turkey clearly would have needed such a patron in 1997. In fact, in contrast to all other candidates, Turkey had a contrary situation, which was that of having a clear adversary within the EU. Long-running political disputes with Greece have meant that Greece historically has served as a major blocking point to Turkish candidacy. 
In 1999, however, relations between Greece and Turkey became warmer due to two factors: the replacement of Theo Pangalos by George Papandreou (who is more moderate in his approach to Turkey) as Greek Foreign Minister and the devastating earthquake in Turkey in August 1999 (which produced an outpour of sympathy and assistance from the Greek government). Greece also had a clear interest in improving its relations with Turkey at that particular time. The Greek aim of participating in the euro zone necessitated budgetary cuts in Greece, specifically in defence spending. Since Turkey was the main focus of Greek defence expenditures, a rapprochement with Turkey would allow a reduction in such expenditures, thereby paving the way for Greek entry into the euro zone. ${ }^{29}$ In addition, according to one EU official, the major reason behind the Greek change of policy towards Turkey was that Greece had traditionally asked for concessions from other EU member states on its disputes with Turkey which in turn weakened its bargaining power on other important issues. By 1999, this trade-off became very difficult to sustain ${ }^{30}$ as Greece was not able to bargain effectively on other EU policies such as structural funds, the euro and justice and home affairs. Thus, the Greeks who firmly resisted Turkey's candidacy in Luxembourg were more compliant in Helsinki, and as the policy preferences of Greece changed between 1997 and 1999, it became possible for the overall policy of the EU towards Turkey to also change.

Besides the Greek opposition due to historical and strategic disputes, the other main problem facing Turkey's candidacy in 1997 was the perception of cultural differences between the EU and Turkey, which was primarily a concern of the German government. In the open-ended section of our interviews with the EU ambassadors, the issue of cultural cohesion was revealed as an important area determining EU member states' preferences towards Turkey's candidacy. According to one ambassador, "the role of culture will be the toughest question to answer for Turkey's membership - even after Turkey fulfils the political and economic criteria - because the European public is very unpredictable and the problem of Europe's cohesion will be a tricky issue." ${ }^{31}$ The underlying concern stems from the perception of Turkish culture as being significantly different from European culture. This view was best reflected with the European People's Party (the Europe-wide Christian Democratic group) declaration of 4 March 1997: "The European Union is a civilisation project and within this civilisation project, Turkey has no place." 32 Accordingly, the former Belgian Prime Minister Wilfried Martens from the Christian Democratic Party stated that "Turkey is not a candidate to become a member of the EU short term or long.",33

Importantly, at the time of the Luxembourg summit of the European Council, the CDU/ CSU under the leadership of Helmut Kohl was in power in Germany. Thus, the preferences of the German government regarding the Turkish candidacy at that time were to a large extent shaped by the perception of vast differences between European and Turkish cultures, a perception that was prevalent among the CDU/CSU. This, in turn, determined German opposition to Turkey's inclusion into the enlargement process at the Luxembourg European Council Meeting. With one of the Big Three against it, Turkey had little chance of obtaining the desired candidacy status.

By the 1999 Helsinki Summit, however, the German government's preferences regarding Turkey had changed considerably. Specifically, when Gerhard Schroeder came to power, one of the things he put on his EU agenda was to ameliorate relations with Turkey. One may note that during the election campaign in Germany, the Social Democrats stressed the need of resolving Germany's Turkish problem and the recognition of dual citizenship. ${ }^{34}$ Moreover, in his speech to the Bundestag on 16 December 1999, Schroeder claimed that: "The decisions of Helsinki are important for the ability of everyone to live together in Germany, regardless 
of their origins. For the many people of Turkish origin living among us, it will be crucial to know whether the land of their fathers will be able to hope for a democratic future in Europe and as a part of Europe." 35 This summarises the Social Democrats' view that in order to deal with the problems of immigration and minority rights at home, Turkey should be included in the larger EU structure. Thus, when the CDU government was replaced by the Social Democratic/Green coalition, Germany's national preferences with regard to Turkey's EU membership changed. This is consistent with the general proposition of the paper that it is the national preferences of the member states that determine EU policy - especially those of the Big Three - and at the same time, it gives us an insight into the change of heart in the EU from Luxembourg to Helsinki.

In fact, in its Council presidency in the first half of 1999, Germany, under Schroeder, tried to reverse the Luxembourg decisions by drafting a proposal for Turkey and presenting it to the European Council in Cologne in June 1999. His proposals were rejected by Greece (for reasons noted above), Italy (probably due to the Turco-Italian crisis of November 1998 over the Abdullah Ocalan case), ${ }^{36}$ and Sweden (due to Sweden's reservations about Turkey's human rights record). However, the German position on Turkish candidacy had clearly changed, paving the way for Helsinki. ${ }^{37}$

Initial evidence of this change can be found in the outcome of the Cologne Summit, in which one of the conclusions of the Council presidency (which Germany, of course, held) was the following: the European Council

emphasises once again the conclusions reached by the European Council in Luxembourg that decisions on the opening of further negotiations can only be taken on the basis of the criteria established by the Copenhagen European Council. At the same time it highlights the importance also attached to the prospect of accession for applicant countries with which negotiations are not yet under way. For this reason it invites the Commission, in its next progress reports, to consider measures which can help crystallise that prospect for all applicant countries. ${ }^{38}$

This was apparently the first step in the process of granting Turkey official candidacy status, although it was not understood in this light at the time.

Beside the clear shift in the German position, another aspect of the Cologne summit that made it possible for the EU to change its policy toward Turkey was the adoption of a new enlargement strategy, the principle of differentiation. ${ }^{39}$ Prior to Cologne, candidate countries were considered in blocks. In fact, scholars have argued that this is the general preference of the EU - to negotiate with candidates in groups. ${ }^{40}$ Also, this was the strategy originally suggested in the Commission's Agenda 2000 report: to absorb the first wave of entrants before negotiating the entry of other candidates. At the Cologne Summit, however, the member states made it clear that they preferred a principle of differentiation, whereby candidates would be engaged in the negotiation process according to their own needs and abilities.

One result of this new approach was that it became less apparent which candidate countries would enter the EU first, and eventually produced the Commission recommendation for a 'big bang' strategy after its most recent evaluation of the candidates. ${ }^{41}$ Such an approach is likely to allow all candidates except Bulgaria and Romania (and, of course Turkey) to enter the EU in 2004.

One of the other results of this new approach, however, was that it made it possible for the EU to open the door to candidates which might be at very different stages of preparation for membership and which did not fit into any of the groupings that the Commission had apparently been developing, without committing to any specific date of entry. With a strategy 
of 'work at your own pace' adopted at Cologne, it became more feasible to allow a country like Turkey, which presumably had some way to go toward fulfilling the Copenhagen criteria, to become an official EU candidate.

This was a fairly major shift in enlargement policy, in that, as indicated above, the EU tends to work with groups of candidates. Indeed, when Portugal tried to dissociate itself from the Spanish candidacy, which the Portuguese government believed to be preventing its own early entry, the EU resisted, and both countries instead entered the EU at the same time. ${ }^{42}$ In addition, the only enlargement that has included only a single country is the enlargement to include Greece. In all other cases (three other enlargements), the EU has preferred to work in pairs or groups of three. Why did the EU suddenly change its general enlargement strategy? First, among the candidates that were not in the top six, there were rumblings of unhappiness at the prospect of remaining in an EU purgatory indefinitely. In other words, people in these countries worried that once the EU allowed the top six candidates to accede, it would be a very long time before any others were accepted. EU leaders perceived that such feelings of hopelessness about EU membership could then derail reforms that were underway in some of the candidate countries. Moreover, the undertones of abandoning the goal of becoming part of Europe from within Turkey were also troublesome. Perhaps most importantly, though, was the fact that the conflict in Kosovo was underway, stimulating concern among EU leaders that the entire region was potentially very unstable, and that they needed to do whatever was possible to ensure that Central and Eastern Europe (including Turkey) remained on the path towards stable democracy. In addition, Romanian and Bulgarian support for the Western Alliance during the Kosovo campaign was influential in the EU's decision to adopt the principle of differentiation and open negotiations with these countries. Thus, the principle of differentiation, or 'work at your own pace' strategy, was likely to be seen as a way to encourage the candidates that had not been in the top six that the EU would indeed accept them when they (the candidates) had met the requirements for entry and that indeed, there was no longer a 'top six' group of candidates anymore. In turn, without the risk of having to wait for decades to join the EU, all of these candidates, including Turkey, would presumably continue to prepare for full membership, and more specifically, would continue on the path towards democratisation.

In sum, at the time of the Luxembourg summit, Turkey had several EU members that would probably have supported its candidacy, had there had not been such strong opposition from the German and Greek governments and had it had a patron. On the other hand, many of the member states such as the Benelux and Nordic countries were mildly opposed due to concerns regarding deepening the EU and the problems in Turkish democratisation, respectively. ${ }^{43}$ As became apparent in 1999, however - as Turkish democracy had not improved by then - these opponents could no longer hide behind German and Greek opposition and were persuaded to move from sitting on the fence to supporting Turkey's candidacy. Indeed, Gerhard Schroeder, in a sense, began functioning like a patron for Turkey almost immediately after coming to power in Germany. ${ }^{44}$ In addition, the member states together committed to changing their enlargement strategy from the traditional community method of negotiating with groups of member states to negotiating with individual member states instead - based on the principle of differentiation - and this meant that there would be no question as to the group of candidates to which Turkey belonged or what its specific entry date might be. ${ }^{45}$

The constructivist approach to enlargement can also offer some explanation as to why this change in enlargement strategy occurred. Specifically, as mentioned above, under the Kohl administration, the German vision of an ideal Europe was one that excluded Turkey, whereas 
Schroeder's ideal Europe is one that includes Turkey. As opposed to the Greek change in policy, which was very rational and self-interested, the German change probably occurred as a result of a change in the definition of what constitutes a collective identity. Thus, while the intergovernmental approach leads us to the conclusion that it was a change in preferences that produced a change in policy, constructivism may provide an insight into the reason for that change.

One should note that understanding these individual member state preferences enables us to explain the change in member states' position towards Turkey; nonetheless, there are collective EU-level factors - i.e., factors that are of concern to all of the member states - that also impact Turkey's candidacy. These are Turkey's adherence to democratic rule, the Cyprus problem and the EU's Rapid Reaction Force (RRF). These issues are addressed in the following section.

\section{POST-HELSINKI ISSUES: DEMOCRATISATION IN TURKEY, CYPRUS, AND ESDP}

Turkish-EU relations changed dramatically after the Helsinki decision to grant Turkey candidacy. On 8 November 2000 the European Commission adopted an Accession Partnership Document for Turkey, which was adopted by the Council on 8 March 2001. Turkey then adopted its National Programme for the Adoption of the acquis on 19 March 2001. At present however, Turkey is the only candidate country with which accession negotiations still have not begun. In the Seville summit of June 2002, the Turkish government asked for a firm commitment from the EU in the form of an accession negotiation start date. ${ }^{46}$ Turkey, in an attempt to signal its commitment to meeting the Copenhagen criteria, adopted a drastic package of political reforms in August 2002, ranging from issues of the repeal of the death penalty to the usage of mother tongue in Turkey. ${ }^{47}$ According to Commission officials, the EU regarded this constitutional package as a "miracle." 48 Thus, there has been clear movement in the direction of addressing this concern regarding the Turkish candidacy, a concern that is shared by all member states.

As a result of these reforms and the insistence of Turkish leaders that Turkey's situation be addressed, in the Copenhagen summit of December 2002 EU leaders agreed to review Turkey's candidacy based on its ability to meet the political aspects of the Copenhagen criteria in December 2004. If Turkey fulfils the Copenhagen criteria at that time, then the EU will decide whether and when accession negotiations could begin. Howevewr, as mentioned above, Turkey continues to remain as the only candidate with which accession negotiations have not yet begun.

In addition, Turkey's membership negotiations are affected by the Cyprus problem and the EU's newly acquired security role, its Common European Security and Defence Policy (CESDP) and the RRF. These are not included in the Copenhagen criteria for accession, but nonetheless, they act as stumbling blocks to Turkish membership. Even though various Turkish governments traditionally argued that Turkey's relations with the EU and the Cyprus problem are two different issues, the EU practice since 1995 is contrary to that. Turkey's candidacy in the EU is further complicated by the fact that Cyprus is about to become a member of the EU and the ongoing division of the island has finally come to a point where a settlement needs to be reached preferably before the Greek Cypriots sign their accession deal.

In the case of Cyprus, the EU as a whole has not wanted to admit a divided country into its ranks, but the Greek government is threatening to derail the entire enlargement process if 
Cyprus is not admitted in the next enlargement by vetoing the Central and Eastern European accessions (through the Greek parliament, which must give its approval to the accessions, as must all member state parliaments). Thus, the EU has been forced to issue statements indicating that Cyprus will be allowed to join the EU at the next enlargement, whether the country is divided or not. ${ }^{49}$

One possible scenario is that, in return for Turkey's support to a solution in Cyprus, the EU could consider giving an accession negotiation start date for Turkey. In other words, Turkey's accession negotiations and Cyprus's accession to the EU could very well be interrelated. For the purposes of this paper, one aspect of the change of EU policy towards Turkey might be related to Cyprus: a Turkey that is in the enlargement process is likely to be more influential in finding a solution to the Cyprus problem than an isolated Turkey. To be more specific, the EU's change of heart towards Turkey in Helsinki might have been partly motivated by the idea of bringing Turkey and Northern Cyprus into the EU's enlargement orbit and creating incentives to facilitate a solution in Cyprus, as clearly Cyprus was on track for membership and a solution did not seem likely with one party being kept at bay. Granting Turkey candidacy in the EU appeared to create new incentives to resolve the Cyprus issue as for the first time in 28 years, Greek and Turkish Cypriot leaders have come together in various contexts since January 2002 to work on possible re-integration scenarios. The UN proposal of November 2002 seemed to present a breakthrough in the Cyprus problem prior to Cyprus's accession.

Directly related to the Turkish candidacy, the Cyprus problem and the changing preferences of the EU member states on a collective level basis are the EU's CESDP and RRF. At the December 1999 Helsinki summit, the European Council adopted a number of measures to advance the CESDP stating its "determination to develop an autonomous capacity to take decisions and, where NATO as a whole is not engaged, to launch and conduct, EU-led military operations in response to international crises." 50 The EU members agreed to build a military force of 50,000-60,000 troops by 2003 through voluntary contributions of member states. This force would be capable of performing and sustaining the full range of Western European Union's Petersberg tasks - humanitarian intervention and peace-keeping missions. The heart of the problem in creating such a force lies in the fact that the EU does not have the operational capability to act on its own when the rest of NATO prefers not to participate in an activity. Thus, the solution developed was to have automatic access to NATO assets and facilities to carry out the EU's activities when NATO chooses not to act. However, the difficulties between Greece and Turkey have also spilled over into the EU's attempt to build its own rapid reaction force. Turkey, as a member of NATO and an associate member of the WEU, asserted that the EU's access to NATO assets should not be automatic but on a case-by-case basis as agreed at NATO's 1999 Washington summit. The negotiations between NATO and the EU over the EU's access to NATO assets were halted by the Turkish position. In an attempt to overcome this difficulty, in November 2001, Turkey, the USA and the United Kingdom developed a common position, the Ankara Document, where they agreed in principle on the EU's automatic access to NATO capabilities, but stipulated that in cases where Turkey's security interests are involved (such as the Aegean sea and Cyprus), Turkey would have to be consulted. The Ankara Document was on the agenda of the December 2001 Laeken summit of the EU, and all the EU members except Greece agreed on the text. Similar to the above argument with regard to Cyprus, Turkey's inclusion in the enlargement process virtually guarantees that it would hesitate more to blocking the EU's CESDP. Thus, one motive for granting Turkey candidacy could be linked to the EU's security aspirations and the difficulties Turkey's exclusion would cause. $^{52}$ This may very well also be the reason behind the strong US support for Turkish membership to the EU. ${ }^{53}$ 
In the Copenhagen summit of December 2002, the EU leaders agreed to review Turkey's candidacy based on its ability to meet the political aspects of the Copenhagen criteria in December 2004. If Turkey fulfills the Copenhagen criteria at that time, then the EU will decide whether and when accession negotiations could begin. Thus, Turkey continues to remain as the only candidate with which accession negotiations have not yet begun.

\section{CONCLUSION}

The issue of EU enlargement and Turkey's membership go beyond a relatively simple analysis of whether the candidates are able to meet the Copenhagen criteria, as is argued by most EU officials. EU enlargement is affected by policy preferences of the member states and their capability to influence EU policy. Evidence of this is that a candidate country such as Romania that was by all accounts a long way from meeting the Copenhagen criteria was included in the EU enlargement process in the Luxembourg summit. Thus, it seems that the decision to grant an aspirant country candidate status is not solely taken in line with that country's ability to meet the Union's criteria but as a result of certain member states' interests and their relative power.

This argument does not favour the view that the Union's enlargement criteria are arbitrary; only that certain countries are more readily accepted than others due to the interaction of multiple factors, the Copenhagen criteria being only one of these. To put it differently, meeting the Copenhagen criteria will probably be a necessary condition, but not a sufficient one for an aspirant country to be included in the EU's enlargement process, and may not, in fact, even be a necessary one, as the case of Poland is likely to illustrate..$^{54}$

All accession negotiations are affected by the policy preferences of the member states precisely for this reason. Even if the candidates could meet all the Copenhagen criteria in their political and economic systems, the above-mentioned factors would complicate their accession to the Union. Issues that are specific to Turkey include perceived cultural differences and Greek opposition because of historical disputes. Indeed it was these two issues that primarily prevented Turkish candidacy in 1997, and, as argued here, it was the change in government perspectives on these issues, along with a major change in the Community approach to the enlargement process in general, that opened the way for candidacy in 1999. This change, it should be noted, has produced the desired effect in Turkey - fairly major political reforms to the Turkish constitution have been adopted in preparation for eventual EU membership, and while more reforms are clearly necessary, the goal of EU membership may keep Turkey on a clear path toward full-fledged democracy.

\section{Notes}

1. Turkey signed an Association Agreement with the EEC in 1963 that foresaw eventual Turkish membership and has the longest standing application (since 1987) for EU membership and a Customs Union Agreement with the EU since 1996. The Maltese government was still wavering on the issue of EU candidacy and so was not made part of the enlargement process until 1998.

2. Romania in particular continued to receive Freedom House scores (www.freedomhouse.org) that were as low as Turkey's throughout 1996 and both Romania and Bulgaria had per capita GDPs that were roughly half Turkey's (Eurostat 2000).

3. Freedom House rankings of Turkish democracy did not change, nor did Turkey's level of economic instability.

4. Metin Heper (2000), pp. 634-68 and Ergun Ozbudun (1996), pp. 123-38. 
5. See Meltem Muftuler-Bac (1997); Lauren M. McLaren (2000); Barry Buzan and Thomas Diez (1999); pp. 41-57; Paul Kubicek (1999); Ziya Onis (2000).

6. The only two member states whose ambassadors we could not interview were Luxembourg - because they have no diplomatic representation and are represented by the Belgian embassy, and Austria - because the Austrians were reluctant to be interviewed, to put it mildly. The interviews were face-to-face, lasted about one hour, based on a survey questionnaire composed of 2 different sections of 15 closed and 15 open ended questions each on enlargement in general and on their countries' perception of Turkey's membership.

7. John Peterson and Erik Jones (1999); Liesbet Hooghe, (ed.) (1996).

8. Wayne Sandholtz and John Zysman (1989).

9. Andrew Moravcsik (1991).

10. The paper's model is derived from Andrew Moravcsik (1993); see also Andrew Moravcsik and Kalypso Nicolaidis (1999).

11. Lykke Friis and Anna Murphy (1999), p. 217.

12. T. Risse, D.E. Martin, H. Knopf, K. Roscher (1999), p. 153.

13. Frank Schimmelfenig (2001).

14. Barry James, Recasting of Europe, International Herald Tribune, 23 April 2001, www.iht.com

15. Address by Mr. Lionel Jospin, Prime Minister, "The future of an enlarged Europe", Paris, 28 May 2001.

16. Speech by Chancellor Gerhard Schroeder delivered before a joint session of the two houses of the Polish Parliament (Sejm) in Warsaw, 6 December 2000.

17. See Müftüler-Bac (1997) for a more thorough discussion of this history.

18. Naturally, this paper is not the first to argue for the importance of individual member state preferences in the formation of EU policy. Andrew Moravcsik has been arguing that this is the case for more than a decade (Moravcsik, 1991, 1993).

19. The interviewees were told that we would not reveal specific details regarding which of them made which statements, so this information has been omitted from the quotes.

20. It should be noted that Germany might also be concerned with the economic benefits of free trade with the Visegrad Three (Schimmelfennig 2001, pp. 50-1).

21. Speech by Chancellor Gerhard Schroeder, delivered before a joint session of the two houses of the Polish Parliament (Sejm) in Warsaw, 6 December 2000

22. A Survey of European Union Enlargement, The Economist (19 May 2001), p. 9.

23. Helene Sjursen (2002), p. 508.

24. Information obtained from interviews with EU member state ambassadors to Turkey.

25. Financial Times (15 September 1997), p. 2.

26. Interview conducted 22 December 2000.

27. The Economist, (19 May 2001), 'A Survey of European Union Enlargement', p. 9.

28. San Francisco Chronicle (14 June 1997), p. A12.

29. Briefing (9 April 2001), issue 1337.

30. The authors' interview in Brussels with an official from the Council of the European Union, 4 September 2002.

31. Interview on 22 December 2000.

32. The Guardian (7 March 1997), online edition.

33. Middle East International (8 November 1996), p. 14.

34. Frederick Studemann, German dual citizenship plan under fire, The Financial Times, (11 Jan 1999) p. 2.

35. Gerhard Schroeder, Policy statement on the results of the European Council in Helsinki, Speech delivered German Bundestag on 16 December 1999.

36. In November 1998, Abdullah Ocalan, the leader of the Kurdish terrorist organisation-PKK, was arrested in Italy. Turkey demanded his extradition and Italy refused. The crisis was diffused when Ocalan was caught in hiding in Nigeria in the Greek embassy in February 1999.

37. It should be noted that current CDU/CSU leadership has echoed these concerns over Turkey. Specifically, Edmund Stoiber, who is challenging Gerhard Schroeder in the upcoming German national elections, has argued that "Europe cannot end on the Turkish-Iraqi border" (Peel, Quentin, and Anton Notz, Stoiber Warns Against Continual EU Enlargement, Financial Times, (17 May 2002), www.FT.com.

38. http://europa.eu.int/council/off/conclu/june99/june99_en.htm, italics added by the authors.

39. See http://europa.eu.int/council/off/conclu/june99/june99_en.htm for the full text.

40. Christopher Preston (1995).

41. See the Commission's Strategy Paper 2001, at www.europa.eu.int.

42. Christopher Preston (1995).

43. Several of the interviews with EU member state ambassadors pointed to this general conclusion.

44. However, one should note that despite his support to Turkey's candidacy in 1999, Schroeder has been lukewarm towards beginning negotiations with Turkey (Radikal, Turkish daily newspaper, 29 November 2002).

45. It should also be noted that one of the reasons the issue of the Turkish candidacy was probably kept on the agenda after Luxembourg was the continual demand by the Turkish leadership that the question of Turkey's status with the Union be addressed more definitively. 
46. Turkish daily newspapers, Hurriyet and Milliyet, 22 June 2002.

47. Interview with Turkish Foreign minister, Sukru Sina Gurel, La Libre Belgique, 5 September 2002.

48. Authors' interviews in Brussels with officials in the DG for Enlargement, 5 September 2002.

49. Turkish Daily News, 4 June 2002, A Divided Cyprus Could Become Member of the EU-Danish Prime Minister.

50. Presidency Conclusions, Helsinki Council, 10-11 December 1999, paragraph 27.

51. Richburg, Keith B. (2002). EU Agrees on Curbs On Illegal Immigration, Washington Post, 23 June 2002, p. A25.

52. Meltem Müftüler-Bac (2000), pp. 489-502; Müftüler-Bac (2001), pp. 379-382

53. Indeed, some might contend that this strong U.S.-based support gives Turkey an important non-EU-member patron.

54. While the EU has presented rather strict requirements for enlargement in the form of the Copenhagen criteria, bargains will probably be struck to include candidates like Poland even if they are behind in meeting the criteria, and this phenomenon, in great part, stems from the preference of one of the most powerful member states, Germany, to include Poland.

\section{References}

Buzan, B. and Diez, T. (1999). Turkey and the European Union, Survival, 41(1), pp. 41-57.

Eurostat. (2000). Statistical Yearbook on Candidate and Southeast European Countries, Yearbook 2000.

Friis, L and Murphy, A. (1999). The European Union and Central and Eastern Europe: Governance and Boundaries, Journal of Common Market Studies, 37(2), pp. 211-32.

Heper, M. (2000). The Ottoman legacy and Turkish Democracy. Journal of International Affairs, (54), pp. 634-82.

Hooghe, L. (ed.) (1996). Cohesion Policy and European Integration: Building Multi Level Governance, Oxford University Press, Oxford.

Kubicek, P. (1999). Turkish-European Relations at a New Crossroads? Middle East Policy, 6(4), pp. 157-73.

McLaren L.M. (2000). Turkey's Eventual Membership of the EU. Journal of Common Market Studies, 38(1), pp. $117-29$.

Moravcsik, A. (1991). Negotiating the Single European Act: National Interests and Conventional Statecraft in the European Community. International Organization, 45, pp. 651-88.

Moravcsik, A. (1993). Preferences and Power in the European Community: A Liberal Intergovernmentalist Approach. Journal of Common Market Studies, Vol. 31(4), pp. 473-524.

Moravcsik, A. and Nicolaidis, K. (1999). Explaining the Treaty of Amsterdam: Interests, Influence and Institutions. Journal of Common Market Studies, 37(1), pp. 59-85.

Müftüler-Bac, M. (1997). Turkey's relations with a changing Europe. Manchester, Manchester University Press.

Müftüler-Bac, M. (2000).Turkey's role in the European Union's Security and Foreign Policies, Security Dialogue, 31(4), pp. 489-502.

Müftüler-Bac, M. (2001). Turkey's Candidacy to the European Union, The Role of Security Considerations, Security Dialogue, 32(3), pp. 379-82.

Onis, Z. (2000). Luxembourg, Helsinki and Beyond: Turkey-EU Relations. Government and Opposition, 35(4), pp. $463-83$.

Ozbudun, E. (1996). Turkey: How Far from Consolidation. Journal of Democracy, 7(3), pp. 123-38.

Peterson, J. and Jones, E. (1999). Decision-making in an enlarging European Union. In: James Sperling (ed.), Two Tiers or Two Speeds: The European security order and the enlargement of the EU. Manchester, Manchester University Press.

Preston, C. (1995). Obstacles to EU Enlargement: The Classical Community Method and Prospects for a Wider Europe. Journal of Common Market Studies 33(3), pp. 451-63.

Richburg, Keith B. (2002). EU Agrees on Curbs On Illegal Immigration, Washington Post, 23 June 2002, p. A25.

Risse, T., Martin, D.E. Knopf, H., Roscher, K. (1999). To Euro or not to Euro? The EMU and Identity Politics in the European Union. European Journal of International Relations, 5(2), pp. 147-87.

Sandholtz, W. and Zysman, J. (1989). 1992: Recasting the European Bargain. World Politics 41, pp. 95-128.

Schimmelfenig, F. (2001). The Community Trap: Liberal Norms, Rhetorical Action, and the Eastern Enlargement of the European Union. International Organization, 55(1), pp. 47-80.

Sjursen, H. (2002). Why Expand? The Question of Legitimacy and Justification in the EU's Enlargement Policy, Journal of Common Market Studies, 40(3), pp. 491-513. 
Copyright $\odot 2003$ EBSCO Publishing 